\title{
Pro Pent: A project for the study of the Pentateuch in South Africa
}

\begin{abstract}
Author:
Jurie le Roux ${ }^{1}$

\section{Affiliation:}

${ }^{1}$ Department of Old

Testament Studies,

University of Pretoria,

South Africa

Correspondence to:

Jurie le Roux

Email:

jleroux1@mweb.co.za

Postal address:

Department of Old

Testament, University of

Pretoria, Pretoria 0002,

South Africa

Dates:

Received: 08 June 2012

Accepted: 22 Aug. 2012

Published: 05 Dec. 2012

How to cite this article: Le Roux, J., 2012, 'Pro Pent: A project for the study of the Pentateuch in South Africa', HTS Teologiese Studies/ Theological Studies 68(1), Art. \#1277, 10 pages. http://dx.doi.org/10.4102/ hts.v68i1.1277
\end{abstract}

C 2012. The Authors. Licensee: AOSIS OpenJournals. This work is licensed under the Creative Commons Attribution License.
This article focused on Pro Pent (or the Project for the Study of the Pentateuch) which was established in August 2000 after professor Eckart Otto from the Ludwig Maximilian University (LMU) of Munich visited the University of Pretoria (UP). Pro Pent is a joint project of UP and the LMU and since 2001 annual seminars drive the initiative. These seminars are held in Pretoria and sometimes in Munich. Pro Pent is now an established international study group on the Pentateuch. In order to understand Pro Pent in the South African context, the article briefly discussed the work of previous South African Pentateuch scholars like John William Colenso, Johannes du Plessis and Ferdinand Deist. Their contributions were firstly assessed before Pro Pent's contribution to the study of the Pentateuch was discussed and its relevancy for the South African context assessed, and highlight Pro Pent's intention to be relevant.

\section{A brief intellectual history}

In August 2000 Pro Pent (or the Project for Pentateuch Studies) was established as a joint project of the University of Pretoria (UP) and the Ludwig Maximilian University (LMU) of Munich. It was the outcome of the right events, which occurred at the right time.

In the year 2000 the members of the Faculty of Theology at the University of Pretoria experienced exciting times and an atmosphere of enthusiasm prevailed. Until that year the faculty was divided into two sections. Section A served students from the Nederduitsch Hervormde Kerk whilst Section B served students from the Nederduits Gereformeerde Kerk. From the beginning of 2000 the two sections became one united faculty. This merger stimulated research and colleagues eagerly took up new challenges and pursued new projects. When Eckart Otto, from Munich, visited us in August 2000 he was the right person at the right time at the right place. He had an immediate rapport with the members of the faculty and was instantly made an honorary professor. All these events favoured the creation of Pro Pent. To rephrase: in August 2000 the socio-intellectual conditions were most favourable for the beginning of a Pentateuch project and we seised the moment.

Pro Pent's beginnings can also be described in four movements. Firstly, the seminars Otto held in August 2000 - these happened twice or thrice a week and were attended by five to ten people - to the few of us it was new, different and challenging; the classical source theory was rejected and the book of Deuteronomy (not Genesis!) suddenly became the point of departure for the study of the Pentateuch. Secondly, by April 2001 we received Otto's book, Das Deuteronium im Pentateuch und Hexateuch (2000a), and were thrilled; it consisted of the lectures he had discussed the previous year and it was furthermore dedicated to the Faculty of Theology of the University of Pretoria (Otto 2000a:VIII). Thirdly, we were so inspired by the book that some of us got together to discuss it thoroughly; Jurie le Roux immediately wrote an article explaining Otto's views to a wider audience (Le Roux 2001b:234-244). Fourthly, Pro Pent 2001 - our first gathering - was shaped by the ideas of this book and it became clear that Eckart Otto's ideas would be used and developed, criticised and adapted for Pro Pent.

Pro Pent soon became a hub where South African and international scholars assembled to discuss the many facets of Pentateuch research. Pro Pent also has an excellent working relationship with Pro Psalms (the Program for Psalm research) and professor Dirk Human which helped Pro Pent in many ways.

\section{International guests}

This year (2012) Pro Pent already exists twelve years and has emerged as an international study group on the Pentateuch. In 2004 and 2007 Pro Pent meetings were held at the Faculty of Theology of Munich and in 2007 Pro Pent was allotted a morning session at the international Society of Biblical Literature's meeting at Vienna. The Pro Pent meetings of 2004 and 2007 in Munich and 
Vienna were attended by German scholars who read papers and contributed to the seminar proceedings. Some of the scholars who attented and contributed were: Reinhard Achenbach (Münster), Friedrich Reiterer (Salzburg), Georg Fischer (Innsbruck, Austria), Christian Frevel (Bochum), Hans Ulrich Steymans (Freiburg, Switzerland), Martin Arneth (Munich), Jorg Jeremias (Munich) and of course Eckart Otto (Munich). Over the years some of these scholars (for instance Hans Ulrich Steymans and Christian Frevel) also attended the Pretoria meetings whilst others like John van Seters (Canada), Georg Braulik (Vienna, Austria) and Theodor Seidl (Würzburg) also came. The Pretoria meetings were always attended by researchers from other African countries, namely, Hillary Nyika (Zimbabwe), Nupanga Weanzana (Central Africa), Emmanuelle Usue (Nigeria) and Liswanisu Kamuwanga (Zambia).

In 2011 the following overseas scholars attended Pro Pent 2011: Hans Ausloos (Université catholique de Louvain, Louvain, Belgium), Jan Dietrich (Theologische Fakultät, Leipzig, Germany), Sue Gillingham (Theology Faculty Centre, Oxford, United Kingdom), Raik Heckl (Universität Leipzig, Leipzig, Germany), Dominik Markl (Heythrop College, University of London, United Kingdom), Simone Paganini (Universität Innsbruck, Innsbruck, Austria) and Thomas Römer (Bâtiment Unithèque, Lausanne, Switzerland and Collège de France, Paris, France).

Pro Pent has indeed become an important international congress where excellent Old Testament scholars meet and discuss matters relating to the Pentateuch in particular and the Old Testament in general. It also heralded the beginnings of a fresh start in South African Pentateuchal studies. The term 'fresh' is used deliberately because except for a few past attempts the critical investigation of the Pentateuch never actually came to full fruition in South Africa and Pro Pent wishes to fill this gap. Below the reason for this 'gap' is explained.

\section{Something passed us by}

The history of Pentateuch research in South Africa highlights some of the problems we have grappled with. It was not so easy to appropriate a critical attitude towards the Pentateuch. Due to many reasons a specific intellectual tradition and a critical approach to the text of the Pentateuch never actually reached us. And this must be taken into account when we consider Pro Pent's efforts.

Pentateuch criticism reflects to a large extent the German mind (Houtman 1994:64-72). Research is a cultural enterprise and mirrors the particular mindset, attitudes and perceptions of a cultural group or a community of scholars. In his great work on the history of the historical Jesus research Albert Schweitzer stated that this scholarship could only have taken place in German theology. Only in the German temperament do we find the combination of 'the living complex of conditions and factors - without which no deep theology is possible' (Schweitzer 1936:1). This is probably also true of Pentateuchal research. And according to Schweitzer four factors contributed to this kind of scholarship: the high level of philosophic thought, critical acumen, sharp historical insight and a religious feeling (Schweitzer 1936:4). A combination of these factors 'produced' a kind of critical scholarship that shaped Old Testament study and the investigation of the Pentateuch up to this day. Within this intellectual context a specific way of reading the Pentateuch was nurtured and a new language (terminology, concepts, hypotheses, etc.) was formulated which shaped our understanding of the Pentateuch (Kraus 1969:80-113). The scholarly community in South Africa had never quite experienced this type of Schweitzerian 'intellectual frame'. ${ }^{1}$

What exactly did we miss? This question can be answered in different ways but a few examples will suffice. Firstly, Gabler's clear distinction between a scholarly understanding of the Old Testament and dogmatics was never really contemplated. ${ }^{2}$ According to Gabler biblical theology was a historical enterprise and not supposed to be merged with or subdued to dogmatic considerations. ${ }^{3}$ Secondly, we never really felt the impact of the Aufklärung. And if it is true that the 'historisch-kritische Wissenschaft' originated during the Aufklärung we never felt the urge to appropriate this approach and its results (Kraus 1969:80-113). Or, to put it differently, we never experienced the pressure to come to grips with the historical-critical method and its important results in our methodological endeavours. ${ }^{4}$ Thirdly, the negligence of a critical attitude also led to a naïve view of history. The new view of history which developed during the 19th century in

1.Johannes Du Plessis confronted the church of his day with critical Pentateuch study which resulted tragically in a heresy trial and a court case. In March 1930 the 'Guardian' of Manchester, England requested Du Plessis to formulate the essence of his heresy controversy and the opening statements of his telegram are extremely important: 'The contest between the synod and myself arises from the conflict important: The contest between the synod and myself arises from the conflict between the newer views on the nature and range of inspiration and traditional beliefs ... South Africa though an active participant in the political and economic movements of the age is somewhat backward in the domain of thought, especially religious thought ... Our universities are of recent institution and have not yet had time to produce a generation of scientifically trained minds ... The Dutch Reformed Synod constituted as it is with half its members worthy elders from the backveld cannot be regarded as a tribunal competent to adjudicate on difficult points of doctrine' (Le Roux 1993:113).

2.See, for example, Gabler (1992:489-502); Saebø (1987:1-16); Sandys-Wunsch and Eldredge (1980:133-158); Merk (1984:1-3).

3.Gabler indeed bequeathed to Old Testament science an approach which had far-reaching consequences. His views already reflect the typical features of later historical Old Testament study. It is striking how Gabler endeavoured to determine the typical features of every author, each book as well as the specific era or context in which it originated. And this interest in the 'original', the initial, the earliest as well as the emphasis on the particular, the peculiar, the unique features of each era and author are very typical of historical understanding. Perhaps this is also an indication that Gabler's thoughts moved in the direction of a 'Religionsgeschichte'. If that is true, Gabler not only paved the way for an Old Testament theology as a distinct field of research, "but also anticipating, as it were, the "history of religions" approach, the very one destined a century or so later to put an end, temporarily at least, to the theological presentation of the religion of the Scripture' (Hayes \& Prussner 1985:66).

4.This method was a historical one: Growth and development were the name of the exegetical game; the development of a text from its earliest to its latest stage had to be traced and described. The text was viewed as a conglomerate of diverse source which originated in different places and at different times: especially because of Wellhausen's work the constituent parts of the text could be identified and their growth demonstrated. The meaning of a text was determined historically: text growth demonstrated. The meaning of a text was determined historically: text meaning was dependent on processes of historical description and reconstruction it was believed that historical investigation 'by shedding new light on the ancient Scriptures, is truly serving genuine religion' (Gunkel 1926/1927:36). The exegete played a vital role: he determined the meaning by means of sympathy, empathy; he had to enter into the spiritual world of the text, he had to relive the past. The Old Testament was part of the Ancient Near East: to many the religion of Israel 'can be interpreted only in the light of the influence of extraneous religions' (Gunkel 1903:389). 
Europe (Germany), never actually took root here. According to this view everything was turned upside down and the existing images of the past were shattered totally. The historical approach became 'ein Sauerteig, der alles verwandelt und der schlieszlich die ganze bisherige Form theologischer Methoden zersprengt' (Troeltsch 1913:730, 1922:729-753). With regards to the Old Testament, this implies that the traditional picture of Israel's past was destroyed once and for all. ${ }^{5}$

There were, however, socio-historical reasons why we have missed the critical attitude of the 19th century as well as a critical study of the Pentateuch. One is the scramble for Africa and its impact on the critical investigation of the Old Testament.

\section{The scramble for Africa}

Ever since the Roman times Europe had a fascination with Africa. It was a mysterious continent from which new things were always expected but about which very little was known. To many it was 'vacant' and a kind of 'res nullius', a no man's land. Except for South Africa there were by the middle of the 19th century still no explorers who have penetrated the interior of Africa's darkest parts on a large scale. And then all of a sudden everything changed dramatically. By the mid-1870s the great scramble for Africa had begun and the continent was mercilessly sliced up into many colonies and protectorates. Five rival nations (Germany, Italy, Portugal, France and especially Britain) overpowered Africa and imposed their will on millions of people (Pakenham 1991:1-50)

British colonisation however, never stimulated critical theological reflection or scholarly investigation of the Bible. This was the reason why the Orange Free State and Transvaal were untouched by the Enlightenment and critical scholarship. Money brought the British to these provinces and especially diamonds and gold kept them here for a very long time. When an African shepherd picked up a strange glittering piece of stone in 1867 it turned out to be a diamond. The Colonial Secretary at that time was so overtaken by this discovery that he boldly stated that South Africa's future would be built on this rock. And how right he was. Vast numbers of Englishmen (like Cecil John Rhodes) flocked to places like Kimberley in search of riches and glory. Ordinary diggers made fortunes, the British Treasury was strengthened and the Cape Colony was redeemed from its dire financial straits. And when gold was discovered in June 1886 near present-day Johannesburg, it caused such a rush that it eventually led to a war between Britain and 'Africa's twin white tribes, the Boers of the Transvaal and Boers of the

5.Troeltsch formulated the principles underlying the historical approach brilliantly According to him the 'sole task of history ... is to explain every movement, process, state, and nexus of things by reference to the web of its causal relations'. This interrelatedness and interdependence of all historical events 'is, in a word, the whole function of purely (historical) scientific investigation' (Troeltsch 1913:718). Secondly, the principle of methodological doubt. Historical work can never attain certainty or provide conclusive answers. Historical reconstruction 'can never b more than an incomplete work of the imagination. Thirdly, the understanding of the past by means of analogy. By means of our own life-experiences and 'analogy of the events known to us we seek by conjecture and sympathetic understanding to explain and reconstruct the past' (Troeltsch 1913:720; cf. Klapwijk 1970:89-105).
Orange Free State' (Pakenham 1991:xvii). For the English it was a long, costly and humiliating war but in the end they triumphed. For the Boers it was devastating blow from which they recovered slowly.

Life in 19th century South Africa, especially in the provinces of the Orange Free State and Transvaal, was not conducive to intellectual stimulation and scholarly research of the Bible. Daily life was a struggle for survival, and education not always a high priority. Institutions for higher education did not exist and this had a detrimental effect on the shaping of critical minds. And to make things even worse, clergymen of the Church of Scotland were imported from 1818 to 1836 in an attempt to challenge liberal ideas and to enhance the process of Anglicising the Afrikaans-speaking people. These pastors joined the Dutch Reformed Church in South Africa and had a considerable influence on the religious life of ordinary church folk. Scripture played a central part in their theology and they encouraged the people to cherish the 'Word' and to abide by it. This attitude, however, cultivated a fundamentalistic view of scripture and enhanced a literal reading of the Old Testament (Le Roux 1992:43-60). With this Scottish mindset it became increasingly difficult to accept and nurture a critical understanding of the Pentateuch (cf. Moorrees 1937:863-944; De Villiers 1975:100-159; Ferreira 1972:1-45; Du Plessis 1919:208-329; Van der Watt 1979:22-61; Hanekom 1959:3-116).

One Englishman with a critical mind did however, come to South Africa and became an important voice for a different understanding of the Pentateuch.

\section{A lonely hero of a lost cause}

On 20 May 1855 an English bishop arrived in the British colony of Natal and his views disturbed many in the Englishspeaking world. His name was John William Colenso (1814-1883) and he challenged the traditional reading of the Pentateuch and confronted the English world with radical new ideas which caused a great uproar in church and society in South Africa as well as Britain. He became the bishop of Natal and took up residence in Bishopstowe, just outside Pietermaritzburg where he stayed for the rest of his life and where Ekukanyeni, the headquarters of the mission, was built. There he investigated the Pentateuch and became notorious for his views. In the end he died a lonely man and an outcast in this remote British colony (Cox 1888:47; Hinchliff 1964:62; Le Roux 1993:91-107). However, he remained the most renowned Pentateuch scholar ever to have worked under our southern sun (Deist 1984:98-132; Rogerson 2003:127-135).

It is interesting to note how Pentateuch research was triggered and executed in South Africa. There was no deliberate link to a specific critical tradition of Pentateuchal investigation or the intention to develop and elaborate such an intellectual tradition. Colenso was first and foremost a missionary who 
devoted his life with enormous dedication, passion and hard work to exactly that course. He was however, overwhelmed by the great South African experience. The people, the geography and his daily surroundings 'caused' him to read the Old Testament differently. Ever since he set foot on (South) African soil he was deeply impressed by the African (especially Natalian) countryside and the Zulu people and these impressions served as a kind of hermeneutical key to his understanding of the Pentateuch and the Old Testament. According to him their way of life, customs and their Natalian countryside corresponded in so many ways to the physical culture of ancient Israel, that the Zulu people and culture became an indispensable link between him and the biblical text. Discussions with them illuminated the text and this close relationship between the Zulu and Israel enabled Colenso to understand the Pentateuch (Old Testament) more profoundly:

\begin{abstract}
... therefore, compelled to discuss all the minutest details with intelligent natives, whose mode of life and habits, and even the nature of their country, so nearly correspond to those of the ancient Israelites, that the very same scenes are brought continually, as it were, before our eyes, and vividly realised in a practical point of view, in a way in which an English student would scarcely think of looking at them. (Colenso 1862:xx)
\end{abstract}

Africa and Africans were thus slowly shaping Colenso's reading of Scripture. The real impulse, however, came from his work on the translation of the Bible into Zulu. During one of these sessions a question was asked which prompted Colenso to a more profound study of the Pentateuch. According to him it happened when he and his Zulu assistants were translating the flood narrative (Gn 6-8). One of the assistants asked Colenso whether he believed everything described in the narrative. 'Is all that true? Do you really believe that all this happened thus ... ?' And Colenso said to himself: 'My heart answered in the words of the Prophet, "Shall a man speak lies in the Name of the Lord?" ... I dared not do so' (Colenso 1862:vii). He immediately set himself to a thorough investigation of the text, the outcome of which appeared in seven volumes between 1862 and $1879 .{ }^{6}$

By March 1862 the essence of his first volume on the Pentateuch was already completed and printed at Bishopstowe. He meticulously indicated the Pentateuch's many historical inaccuracies and seriously questioned the Pentateuch's historical reliability (Colenso 1862:33-60). Although the work sold very quickly it caused 'a tremendous commotion in the religious ... English world about it' (Guy 1983:126). So much so that a heresy trial was brought against Colenso and although the Privy Council rejected the validity

6.During the 1920s Johannes Du Plessis confronted the Dutch Reformed Church with the historical critical approach. He was a professor at the Kweekskool (the theological seminary of the Dutch Reformed Church in Stellenbosch) and founded a monthly journal, Het Zoeklicht, in 1924 to promote the discussion of theological questions critically. Du Plessis was also driven by a pastoral motive. According to him much attention had been devoted to matters pertaining to church polity, missions and race relations but in the long run the church neglected its intellectua obligations. Consequently the church became ignorant of the developments in the field of biblical studies and this could not be tolerated anymore. The church would pay dearly for this ignorance by losing the critically-minded churchgoer and become irrelevant. The results of the 'higher criticism' thus had to be embraced (Deist 1988:100). of the charges and overruled the church's accusations he was nevertheless excommunicated from the Anglican Church in South Africa. ${ }^{7}$

\section{A strange dichotomy}

In South Africa Pentateuch criticism has always been experienced as extremely harsh, severe and unkind to belief. Right from the beginning critical views were only tolerated if it could be 'proven' that it did not destroy faith. And to accomplish this a kind of 'theological or philosophical framework' was needed. In other words: to accommodate these critical views a specific kind of 'theological or philosophical framework' had to be designed which would allow scholars to be critical but to remain good believers at the same time (Barth 1972:482-490; Rogerson 1984:19-85). This kind of 'framework' is very typical of our scholarly endeavors and excellently illustrated in the works of Pentateuch scholars like John William Colenso and Johannes Du Plessis.

It was the philosophy of Samuel Taylor Coleridge (1772-1834) which enabled Colenso to remain a devout missionary as well as a critical scholar. According to Coleridge there were two kinds of 'scientific information': the empirical and the spiritual. Empirical data were 'understood' and spiritual things were 'known' in a particular way. Underlying Coleridge's views was a philosophical idealism that placed faith and knowledge of God above and beyond the understanding of the world. According to Coleridge a close relationship exists between the understanding and the senses. By means of our senses an understanding of the world is achieved. This is the realm of science.

In the realm of religion things happen differently. God calls his followers to an awareness of a spiritual reality. Humans have spiritual faculties that enable them to grasp spiritual things. Religious knowledge and worldly understanding are therefore two kinds of knowledge. Understanding is related to the 'science of phenomena'; reason, the 'organ of the supersensuous', is in search for ultimate ends (Reardon 1966:240). Faith is thus a matter of reason.

For Colenso, Coleridge was a godsend (Le Roux 1993:104-106). The latter's views convinced him that a critical scrutiny of the Pentateuch could not harm faith in any way. Since faith is based on spiritual experience it is shielded from any scholarly or historical-critical attacks. All the inaccuracies that are evident in the Pentateuch, and which Colenso so cleverly indicated, must be viewed as empirical work that is related to

7.The church nevertheless decided to ignore Colenso and to pay no attention to his critical investigation of the Pentateuch. He then slowly slipped into oblivion and his publishers became more and more reluctant to publish his works. No one in Nata - that remote British colony - was interested in what he was doing. In the rest of the world it was especially the Dutch scholar Abraham Kuenen who initially took a keen interest in Colenso's work. Colenso also had good relations with Hermann Hupfeld and even tried to visit him in Halle but 'he was out upon his summer tour as I suppose' (Houtman 2003:101). Wellhausen (2001:346) did refer to Colenso but it was especially from his correspondence with Kuenen that Colenso's importance it was especially from his correspondence with Kuenen that Colenso's importance for 19th century Pentateuch scholarship becomes clear (Houtman 2003:76-103) Sarah Frances, Colenso's wife, formulated it very poignantly in a letter (dated 03 October 1884) to Kuenen: 'My dear Dr Kuenen', she begins, 'we are very gratefu for hearing your testimony to the value of my dear Husband's critical work. And in another letter to Mrs Katherine Lyell Sarah, Frances wrote in similar vein: 'I had letter from Prof. Kuenen ... He always spoke in terms of affectionate friendship of my dear Husband, and he was one who could appreciate his work' (Houtman 2003:76). 
the understanding (in the sense of Coleridge). No empirical or mathematical knowledge can therefore exert any influence on reason (in Coleridge's sense). Both are different activities and cannot prove or deny each other. This dualistic view of the Bible and science is very important (Chadwick 1971:7-23). It enabled a missionary like Colenso to execute his parochial work and to investigate the Pentateuch critically. But it also became very typical of South African scholars in later years. As will become clear below, historical-critical study was impossible without a framework safeguarding faith. ${ }^{8}$

Colenso's work became typical of some South African Pentateuch scholars. First of all the main incentive for a critical study came from pastoral considerations. Although the results were harsh and often perceived as undermining faith there was always a philosophical or theological framework, which toned things down. Such a framework enabled scholars to be believers and critics at the same time. And the most important consequence of Pentateuch research was to serve the church and ministry. This was also Colenso's conviction. In a paper read in 1867 to a group of men in Durban (Natal) he clearly expressed the hope that one day the importance of criticism, history and geography for understanding the Old Testament's:

origin, its composition, the ages and habits and modes of thought of its writers, of their times, and of the nations that lived around them, and by whose religion and philosophy they were affected will be fully realized. And we shall find in all, as I am deeply persuaded, - fresh support for a living faith in God, fresh proofs of a Divine revelation ... fresh tokens of a Fatherly Love manifesting itself continually, whether in the Bible or out of the Bible, to the hungry, longing heart of man. (Guy 1983:176)

\section{The years in between}

After Colenso no one continued his line of research and reasoning. The tides were also turning against critical scholarship. Du Plessis's investigations were nipped in the bud and the result was a fundamentalistic approach to the Old Testament (Deist 1986a:36-65). Although Adrianus van Selms (Van Selms 1976:9-63), Charles Fensham (1963:133-143, 1960a:333-335, 1970:23-27, 61-74, 93-98, 1960b:1-2, 1960c:59-60; 1959:273-274, 1962:129-39), and Albertus van Zyl (1976:101-115) made important contributions, critical Pentateuch study just could not get off the ground. In 1971 this worsened when the academic community opted for the linguistics of De Saussure. This new movement reflected a specific approach (a concentration on the final text and a rejection of information about the text's historical growth) as well as

8.Like Colenso, Du Plessis also had to adopt a philosophical scheme to convince the church of the importance of historical criticism. He did that by resorting to Hegel's scheme of thesis, anti-thesis and synthesis. Du Plessis's basic thesis was that the Bible is a human book filled with errors: to him the human nature of the Bible was of extreme importance and errors and mistakes are therefore characteristic of the Bible and the church need not have to shun from them. Over against this thesis stands the antithesis: the Bible is the inspired Word of God: not only the human nature but also the divine nature of the Bible must be fully recognised. And then follows the synthesis: the Bible is a divine and a human book: the human and the follows the synthesis: the Bible is a divine and a human book: the human and the divine aspects of the Bible must never be separated. The human side of the Old Testament can thus be scrutinised critically without harming the divine element Historical criticism is merely a neutral method which cannot deny the supernatura element in the Pentateuch nor undermine the main elements of Christian faith. Thi intellectual frame Poritical scholar as we as a minister in the church (Du Plessis 1926a:80-87, 1926b:100-106, 1926d:148-150 1927:23-26) a specific terminology (diachrony, synchrony, structural analysis) that would be decisive for the future developments of biblical scholarship in South Africa (Vorster 1971:139148). Everything was completely new, biblical scholars followed the trend and the outcome was a new approach that subsequently received the status of a 'normal science' (in the Kuhnian sense) (Kuhn 1970:10-42). This movement had an enormous effect on the study of the Old Testament. An enthusiastic group of young scholars eagerly devoted themselves to a painstaking analysis of the text. New ways of approaching and understanding the Old Testament were discovered and described. This, however, did not lead to a critical understanding of the Pentateuch. Quite the contrary happened. This radical concentration on the final text in a De Saussurean way made historical investigation and Pentateuch criticism outdated and obsolete (Le Roux 1993:270-299).

Nearly a century after the death of Colenso, Ferdinand Deist picked up the threads again (Deist 1983a:73-88, 1983b:26-48, 1986b:159-172, 1975:127-138, 1976a:5-10, 25-30, 1986a:36-65, 1984:98-132, 1983c:1-25, 1977:325-357, 1983c:23-39, 1978:1-100). After Colenso, he was the first South African who approached the Pentateuch in a true historical-critical manner. The academic year that he spent in Marburg with Otto Kaiser enabled him to appropriate and understand especially the German critical or scholarly mind. He was not only acquainted with the method but also the philosophy and theory of science underlying this critical study of the Pentateuch. This enabled him to understand the Pentateuch critics and to penetrate their theories intellectually. No other South African Old Testament scholar has immersed himself or herself so completely in the works of critical Pentateuch scholars as Deist. He examined them carefully, understood their views thoroughly and this resulted in a book on the history of Pentateuch research which was first published in Afrikaans and then in English (Deist 1976b:1-30, 1988:1-29). This was the first book on Pentateuch scholarship ever to have appeared in South Africa and it confronted the academic community with a long forgotten tradition. With Deist's untimely death on 12 July 1997 at the age of fifty-two, his Pentateuch study was brought to an abrupt close.

As the 20th century was drawing to a close the community of biblical scholars was dealt one blow after the other. Apart from Deist other key figures also passed away and the bereaved community struggled to overcome these losses. In the light of the above-mentioned, the creation of Pro Pent, the partnership with the University of Munich, and especially the collaboration with Eckart Otto were of great importance for Pentateuch study in particular, and for Old Testament scholarship in general in South Africa. The efforts and contributions of our Munich colleague in this regard can never be overestimated. Also due to his endeavours Pro Pent seminars were held on a regular basis. These seminars were initially held at Hammanskraal (starting in 2001) but since 2006 at Bass Lake outside Pretoria. Here a group of scholars devote themselves annually for a few days to the study of the Pentateuch. 
For Pro Pent the collaboration with Eckart Otto occured at a time when existing theories and views with regard to the Pentateuch came under severe pressure. A serious attack was for instance launched on the Yahwist and according to some the 21st century could easily dispose of the Yahwist. ${ }^{9}$ In a similar vein the existence of a Deuteronomistic history was also questioned. Some scholars simply denied such a history and refused to use this theory anymore (De Pury \& Römer 2000:9-14). Otto's insights enabled Pro Pent to take a new look at the problems of Pentateuch criticism and to follow new avenues. A new starting point for Pentateuch research was formulated ${ }^{10}$ and knowledge of the neo-Assyrian became indispensable. ${ }^{11}$ Furthermore the concepts of a Deuteronomist and a Deuteronomistic history were formulated in a new way, ${ }^{12}$ the 'ethical dimensions' of the Pentateuch research were stressed and the laws in the Pentateuch became amongst other things important for the discussion on human rights. ${ }^{13}$ The introductoin of Max Weber's thoughts into Pro Pent's activities and his intellectual challenge to Old Testament scholarship were especially significant. ${ }^{14}$ Weber highlighted the power of religious ideas and how these ideas shaped

9.In a work by J.C. Gerz, K. Schmid and M. Witte this ideal was clearly formulated 'Das mag aufregender klingen, als es ist, denn de facto ist der Jahwist in vielen vorgangigen Publikationen bereits verabschiedet worden und unerläutert kann ih heute niemand mehr in die Diskussion einbringen, was auf dasselbe herauskommt: Ein "Jahwist", den sich jeder selber zurechtlegen kann, ist keiner mehr. Der vorliegende Band konstatiert und dokumentiert so den Abschied vom Jahwisten eher, als dass er ihn fordert. Ob er damit im Recht ist, wird sich gleichwohl weiter erweisen müssen. Er hatte sein Ziel erreicht, wenn die Pentateuchforschung im 21. Jahrhundert ohne den Jahwisten auskommen könnte' (Gerz \& Schmid 2002:VI).

10.For a long time the theory prevailed (in South Africa) that the whole Pentateuch must be seen as consisting of the incorporation of the $J$ narrative as expanded with must be seen asconsisting po the incory fration of the tharrative as expanded with This par This paradigm or frame of thought created an arsenal of words and concepts (like Pent, the Pentateuchal narrative), a specific view of Israel's history (emphasising the time of David and Solomon as the era of the Pentateuch's beginnings) and a specific way of exposition of the Pentateuch (starting with a literary critical analysis of Genesis). Due to the views of our colleague from Munich, Pro Pent, however, took advantage of an important paradigm change in Pentateuch study according to which Pentateuch study must begin with Deuteronomy (cf. Le Roux 2001b:234-244). Deuteronomy is now seen as the cradle of the Pentateuch and must therefore serve as starting point. Put differently: Deuteronomy is like a key unlocking the Hebrew Bible's literary history and the reconstruction of Israel's and Judah's 'Religionsgeschichte' (Otto 2002a:1). Pentateuch study should thus form part of Deuteronomy research and Deuteronomy needs to be interpreted as an integral part of the literary history an the Pentateuch. According to Otto the Pentateuch pawes its existence to the (to theological con entsteht durch den Ruckgriff auf Konzeptionen des Deuteronomiums.... sonder vor allem auch die dir Fortschreibungen des dtn Deuteronomiums die Weichen fur . In short: knowledge of the origins of Deuteronomy, the new Archimedes poin of all Pentateuch research, is indispensable for understanding the Pentateuch. Deuteronomy is therefore 'die Wiege des Pentateuch' and it is pity that a certain kind of 'Deuteronomiumvergessenheit' prevails in presentday Pentateuch research (Otto 2000f:1, 1997a:321-339, 1999c:693-696).

11.It was especially the oath of loyalty to Esserhaddon (of $672 \mathrm{BC}$ ) which Judah's intellectuals took over and thoroughly reworked during Josiah's reign which became very important for Pro Pent (Otto 2002a:12, 178, 180): 'Für die Deuteronomiumsforschung ist es von Bedeutung, dab die neuassyrischen Treueide nur im Kontext der irregularen Thronfolge Asarhaddons und Assurbanipals in den Jahren zwischen 683/2 v. Chr. und 669/8 v. Chr. belegt sind ... Weder aus neubabylonischer noch aus persischer Zeit sind Treueide überliefert' (Otto 1999e:32).

12.Noth's views of a Deuteronomistic history contributed to this forgetfulness Deuteronomy was now separated from the Tetraeuch and formed an introduction to the Deuteronomistic history. This view is presently under pressure and in Otto's views the Deuteronomist is now restricted to the two redactional layers DtrD en DtrL. Only those sections which correspond to these layers can be called Deuteronomistic (Otto 2000a:266-273): 'Nur wenn sich eine direkte Ubereinstimmung mit dem Deuteronomium in Sprache und theologischer Konzeption herstellen läbt, ist ein Text als "deuteronomistisch" zu bezeichnen' (Otto 2002a:4). And genuine Deuteronomistic literature in the Hebrew Bible can be found in Deuteronomy and Joshua, and in some sections of Kings and Samuel only.

13.Otto (1998:1876-1877, 1999a:625-628, 1999c:693-696, 1999d:1603-1606, 2000b:702-704, 2000c:741-743, 2000d:822-823, 2000e:845-848, 2000f:1570-1571, 1997b:197-209, 2002c:167-195).

14.Or as Otto has formulated it himself: 'Man wird dem Werk M. Webers am ehesten gerecht, indem man es nicht nur exegesierend und systematisierend reziptiert,
sondern ... in einer gewandelten Forschungssituation eine neue "Religionssoziologie sondern ... in einer gewandelten Forschungssituation eine neue "Religionssoziologie
des antiken Israels und Judas" schreibt' (Otto 2001b:1-188, 888, 2002b:276). the world by creating groups following their own interests. These views are of great importance to Pro Pent (Le Roux 2004:743-753).

\section{Pro Pent's intellectual horizon}

Right from the beginning Pro Pent's intellectual framework was a key issue. It had to function within a specific context and be connected to a certain scholarly tradition. It was, however, soon decided that Pro Pent had to be integrated into the South African tradition of biblical scholarship but also be linked to Pentateuch criticism since the 19th century. Put differently: since Western thinking and scholarship have shaped Pentateuch and Old Testament research profoundly this intellectual tradition must never be abolished but be integrated in our own context. To accomplish this some important premises had to be taken into account:

- The existing critical paradigm for the understanding of the Pentateuch is still valid and will not be substituted easily. But what does such a paradigm entail? It contains the convictions, values and techniques, which a certain group of investigators of the Pentateuch have adhered to over many years; it provides the apparatus (theories, concepts and methods) to understand the Pentateuch. Some aspects of this critical paradigm became typical of Pentateuch investigation: the text of the Pentateuch originated in different life contexts; the final text of the Pentateuch represents only one moment in this huge movement; the complicated history of Pentateuch interpretation is indispensable for its understanding; despite limitations the existing theories of the Pentateuch remain powerful instruments of explanation. ${ }^{15}$ Since Colenso and Du Plessis such a critical approach to the Pentateuch has indeed been part of our scholarly tradition but due to religious reasons ('historical criticism undermines Scripture') and methodological considerations ('sinchrony precedes diachrony') this was not developed fully. Pro Pent aims at linking up with this critical tradition and to elaborate it further.

- Historical critical study remains a very efficient way of describing the historical origin and growth of the Pentateuch. ${ }^{16}$ During the 20th century this way of studying the text came under great pressure and its shortcomings were exposed dramatically. On the other hand the limitations and weaknesses of all the other methods were also realised and it was stated that each method is socio-historically determined; that it is merely a play and cannot yield the final meaning of a text. Thus: a method is nothing more than a specific approach which highlights the meaning of a text from one and only one vantage point. The importance of historical criticism is the fact that it sheds light on historical problems (like origin, growth, life context, etc.) and historical understanding (to comprehend texts within possible historical contexts) (Gadamer 1990:9-15, 108-129, 133-139, 276-290).

15.See, for example, Thiselton (1980:103-113); Otto (2002b:276-313); Von Rad (1958:13-109); Grondin (2001:86-124); Grondin (1994:24-39); Le Roux (2001b:444-457); Mehlhausen (1984:43-65); Rogerson (1984:79-90, 138-144); Schmid (1999:358-379); Noth (1972:1-7); Gottwald (1985:135-147); Albertz Schmid (1999:358-379); Noth (1972:1-7); Gottwald (1985:135-14
(1992:17-43); Collingwood (1994:441-442); Pannenberg (1970:15).

16.See for example, McBride (1981:530-543); Seebass (1982:520-524); Seebass (1987:441-451, 1996:185-209); Schmidt (1991:211-222); Schmid (1999:211-222) 
- Theories about the Pentateuch will always remain crucial and the critical reflection on possible theories will remain an essential mental activity. Pentateuch theories are indispensable because they are the nets we cast to catch what we call 'the world'. By means of theories we endeavour to rationalise, to explain and to master this world. In short: through theories we get glimpses of reality (Popper 1968:59). For instance we 'know' Abraham by means of Pentateuchal theories. Put differently: the historical Abraham is forever beyond our reach, but he comes to life through the many theories regarding the reading and understanding of the Abraham narratives (and the Pentateuch). Pentateuchal theories are therefore like midwives facilitating the birth of endless new images of Abraham. To busy oneself with Abraham implies the critical digestion of Pentateuchal theories. ${ }^{17}$

- Another theoretical aspect deals with the history of research. By taking this seriously we are continuing the line, which Deist began. According to Hans-Georg Gadamer all these interpretations of the past must not be regarded as meaningless or irrelevant. It can help us to understand and to discover forgotten aspects of Pentateuch interpretation. Gadamer calls this continuing process of interpretation and re-interpretation 'die Wirkungsgeschichte' of a text. The 'Wirkungsgeschichte' of Pentateuch criticism is a kind of a historical movement that influences the reading of texts and the understanding of history even here and now, consciously or subconsciously. The history of the interpretations of the Pentateuch co-determine its understanding. A text cannot be understood on its own and detached from previous interpretations, it's meaning cannot be comprehended. The Pentateuch's long research history must therefore be appropriated and integrated within Pro Pent's endeavours. ${ }^{18}$

Pro Pent's intellectual context can thus broadly be described by expressions like 'history of research', 'Pentateuchal theories', 'historical criticism', 'historical understanding', 'origin and growth', 'life contexts', 're-interpretation', et cetera. Within the context of Pro Pent these are merely very broad lines and can be interpreted in many different ways. There is, however, another important feature of Pentateuch study which we constantly reflect on and that is 'relevance': the meaning of Pentateuch study for today. It can at least be answered in two ways. One is to think it through for today and provide practical guidelines. Another is first to

17.Thus, when studying the Pentateuch, theories are all that we have. Any study of the Pentateuch must be undertaken from a particular theoretical point of view. The text of the Pentacuch does not speak for itself; words, concepts and laws in the Pentateuch can only become alive by means of the many different theories. In short: without a theory the Pentateuch cannot be "known'. Pentateuchal theorie function like a searchlight scanning the texts: that which are eventually regarded as Deuteronomy or P, before or after the exile, depends on the searchlight (theory) which makes understanding possible (Popper 1963:1-111).

18.See, for example Gadamer (1990:305-312, 346-352). We are thus never alone because the 'past' of the Pentateuch text joins in the conversation. Understanding does not 'happen' simply due to an objective act carried out by a subject using an objective method, rather, understanding is a process in which we become part of the history of the understanding of the text. Put differently: being human (or being a Pentateuch scholar) implies that we are never detached from the past: we being a Pentateuch scholar) implies that we are never detached from the past; we are subjected to history; we do not make history but history makes us; therefore the history (Wirkungsgeschichte) determines our understanding; this helps us to comprehend texts (Gadamer 1990:295). In another well-known quote Gadamer says that Wirkungsgeschichte is rather being than mind. 'Wirkungsgeschichtliches Bewusstsein ist mehr Sein als Bewusstsein' (Gadamer 1993:101). History (or 'Wirkungsgeschichte') penetrates our whole existence in such a complete way that we can never escape it. understand the inner dialogue in the Pentateuch itself, to determine how the authors of the Pentateuch retold and actualised their theological traditions and made their history relevant for their own times and context.

Below we illustrate this point by briefly explaining the terms 'aktualisierende Neuinterpretation' and 'Vergegenwärtigung' as well as the notion of 'two time slots'.

\section{Re-interpretation and actualisation}

One aspect of Gerhard von Rad's theology became an integral part of Pro Pent's thinking about the Pentateuch and that is the notion of re-interpretation and actualisation (aktualisierende Neuinterpretation and Vergegenwärtigung) of Israel's traditions. Actualisation (Vergegenwärtigung) was an attempt to bring closer that which is far, to make the past present, to make history relevant for today by means of constant reinterpretation; to make past and present contemporaneous, to bring past and present together by means of a never-ending process of reinterpretation (Von Rad 1971:9-80). This notion of actualisation of the past was the driving force behind Israel's constant actualisation of the past.

To explain it once again: God's mighty acts in the past (the creation, the patriarchs, the exodus, the desert experience, Sinai and the conquest) were interpreted by Israel within the context of faith - these were not historical facts, but a history which was formed and shaped by faith. These acts were continuously reinterpreted (Von Rad 1960/1961:213-216) and this continuous reflection led to interpretations relevant for their own day. Israel continually actualised this history - the past became so relevant for the present that the people were encouraged to carry on with their daily lives; Yahweh's history with them assured them that their tomorrows would not be less meaningful than their yesterdays. This 'salvation history' was for Israel also the foundation of their future expectations: the mighty acts of God in the past shaped their future expectations because they expected a new exodus, a new covenant, a new Davidic king, et cetera (Von Rad 1958:125-132). In short: faith demands reflection upon history and the reinterpretation of the past in such a way that it encourages people here and now.

And the scholar of the Pentateuch has the obligation to explain and describe this process of reinterpretation and actualisation. In other words: Pentateuch study must focus on this Vergegenwärtigung or actualisation of old traditions in new contexts. Or as Von Rad (1967) has put it:

And in this way there comes more clearly into our field of vision that part of Israel's theological activity which is probably one of its most important and interesting ones, namely those ever new attempts to make the divine acts of salvation relevant for every new age and day -- (it was) this ever new reaching-out to and avowal of God's acts which in the end made the old credal statements grow into such enormous masses of traditions (p. vi, [my emphasis])

In the context of Pro Pent this notion of reinterpretation and actualisation is a very important one and Eckart Otto's distinction between two time slots is a very effective 
way of understanding the process of reinterpretation and actualisation in the Pentateuch. Put differently: a conscious effort to read the Pentateuch in terms of two slots illuminates the way in which Israel reinterpreted their past in order to give people hope.

\section{Two time slots}

We can illustrate Otto's views on the two time slots by means of the first Deuteronomistic redaction of the book of Deuteronomy. Also called 'DtrD'. Through this redaction we see how the idea of reinterpretation and the reliving of the past enabled the exiles to understand themselves: to realise the utter misery of their situation and to formulate hope against all odds. And Otto 'succeeded' in showing this by distinguishing between two time slots: narrated time and time of narration. The first refers to an 'original' or 'earlier event' and the second to the time of reinterpretation, reapplication and reliving (Otto 2000a:237-243, 2002a:29-32).

To explain this, we first focus on the 'time of narration' or the time of reinterpretation of a past event. The 'time of narration' of the first Deuteronomistic redaction refers to the bleak conditions of the Babylonian exile when the Zadokite priests struggled with very painful questions. One question dealt with the reason for all the destruction and damage to human life. Who was to blame? Whose fault was this? It was clearly stated that God was not to be blamed blame should be cast upon the people, whose love for other gods had caused the tragedy of the exile. They broke the first commandment, worshipped other gods and brought unbearable suffering upon themselves. Then there was a second and more decisive question: did Israel have a future? If so, how did the Zadokites go about to encourage the exiles (Otto 2005:22-49)?

The Zadokite intellectuals could only answer these nagging questions by reinterpreting an earlier period in their history in such a way that it would have meaning for them in the exile. They then brilliantly relocated the time of the exile (or the time of narration) to an earlier event (the narrated time), to the time of Moses and the events at Sinai, the giving of the Decalogue, the golden calf episode, Moses' intercession and the reissuing of the Decalogue (Dt 9:9-21; 10: 1-5). This sequence of events underscores the fact that despite the people's transgression of the main commandment, God forgave them and His covenant of Horeb remained intact. And the Zadokites in exile used this history to give hope to the exiles (Otto 2007b:29-53).

They 'accomplished' this by means of relating two time slots, 'narrated time' and 'time of narration', to each other - by relating their own exilic time to that of Moses. The first time slot ('narrated time') referred to Moses (Sinai, the Decalogue, the golden calf, the reissuing of the Decalogue) and the second to the exile, which also formed the narrative perspective of the Zadokites during exile. In this way transparency between the two time slots was created so that the exiles could re-enact the time of Moses (Sinai and Horeb,
Decalogue, golden calf, etc.) in their minds, relive it in their exilic context and become involved in the events of the past. In this way narrated time and time of narration overlapped and the exiles could identify with the predicament of the people in the time of Moses - they could discover themselves in this generation and start to reshape their lives (Otto 1997a:321-339, 1999c:693-696, 2000g:43-83, 2007a:19-28).

Otto's distinction between 'time of narration' and 'narrated time' opened up new possibilities for our understanding of the Pentateuch and in the many sessions of Pro Pent we used these slots with great success. It also greatly contributed to our understanding of 'aktualisierende Neuinterpretation' and 'Vergegenwärtigung'.

\section{In conclusion}

To make Pro Pent's scholarly work meaningful for our context requires an ear to listen to the past. Put differently: to hear the voices of generations of Israelites who grappled to understand God amidst their daily struggles against fear, pain, poverty, injustice, disease, famine, drought and death; to understand how they interpreted God in the different epochs of their history; to appreciate the tensions in the text as indications of living people who really lived and who found consolation in the constant reflection on God's great acts in history; to comprehend how each generation actualised their past and relived the great acts of God in their times; to realise the joy of reinterpreting God's words for different times (cf. Kaiser 2003:393-424).

This of course is not that easy because the past is an immeasurable stream of events which flows unendingly towards eternity - no one can master this infinite stream nor formulate its meaning in final terms, each one of us is rather constantly overwhelmed and engulfed by an endless torrent of concrete events without ever mastering it. The intellectual contexts from which this stream (read: Pentateuch) is viewed and scholarly analysed constantly shift; the points of departure (Deuteronomy, Enneateuch, etc.) constantly change, and these give rise to new theories and perspectives (Weber 1949:1-50).

This is however, not the end of the road. Caught up in this endless stream of events one can, like a fisherman, constantly be engaged in casting out and pulling in nets without knowing beforehand what the catch is going to be like. Theories (about the Pentateuch) can be like these nets. And when pulling in the nets new unexpected dimensions of the text can be experienced. And this is exactly what Pro Pent aims to do. Here, in this remote southern tip of Africa Pro Pent wants to cast out the nets in the hope that the catch will feed many on this continent.

\section{Acknowledgements}

Piet Venter was for many years head of the Department of Old Testament Studies at the University of Pretoria and this article is dedicated to him out of gratitude for his valuable support of Pro Pent's activities and for the excellent papers 
he has read at Pro Pent since 2001. Without this support it would have been very difficult to keep Pro Pent afloat and to grow in stature and importance. Pro Pent thus wishes our colleague Piet Venter all the best for the future and may we still benefit from his knowledge.

\section{Competing interests}

The author declares that he has no financial or personal relationship(s) which may have inappropriately influenced him in writing this article.

\section{References}

Albertz, R., 1992, Religionsgeschichte Israels in alttestamentlicher Zeit, vol. 1, Vandenhoeck \& Ruprecht, Göttingen.

Barth, K., 1972, Protestant Theology in the Nineteenth Century, SCM, London. Chadwick, O., 1971, The Victorian Church, vol. 1, Adam \& Charles Black, London.

Colenso, J.W., 1862, The Pentateuch and Book of Joshua Critically Examined, vol. 1, Longmans, Green, London.

Collingwood, R.G., 1994, The Idea of History, Oxford University Press, Oxford.

Cox, G.W., 1888, The life of John William Colenso D D, Bishop of Natal, vol. 1, Ridgway, London.

De Knijff, H.W., 1980, Sleutel en slot, Kok, Kampen.

De Pury, A., 2000, 'Abraham: The Priestly Writer's "ecumenical' ancestor"', in S.L. McKenzie \& T. Römer (eds.), Rethinking the Foundation, pp. 163-181, Walter de Gruyter, Berlin. http://dx.doi.org/10.1515/9783110805802.163

De Pury, A. \& Römer, T., 2000, Israel Constructs its History, Sheffield Academic Press, Sheffield. (JSOTSup 306).

De Villiers, D.R., 1975, Teologiese Opleiding vir Wit en Swart deur die Ned. Geref. Kerk in Suid-Afrika, NG Kerkboekhandel, Pretoria.

Deist, F.E., 1975, 'Gen 32:22-32: Geskiedenis en Eksegese van 'n Teks', Nederduitse Gereformeerde Teologiese Tydskrif 16, 127-138.

Deist, F.E., 1976a, Historiese Heuristiek, Teologiese Hermeneutiek en Skrifgesag, UPE, Port Elizabeth.

Deist, F.E., 1976b, Mosaïek van Moses, Pentateugnavorsing sedert die Reformasie, Tafelberg, Kaapstad.

Deist, F.E., 1977, 'Stilvergleichung als literarkritisches Verfahren', Zeitschrift für die Alttestamentliche Wissenschaft 89, 325-357. http://dx.doi.org/10.1515/zatw. 1977.89.3.325

Deist, F.E., 1978, Towards the Text of the Old Testament, NG Kerkboekhandel, Pretoria.

Deist, F.E., 1981, 'The Problem of History in Old Testament Theology', OTWSA/OTSSA 24, 23-39.

Deist, F.E., 1983a, 'Again: Methods of Exegesis', Old Testament Essays 1, 73-88.

Deist, F.E., 1983b, 'Bibelinterpretation und/als Ideologiekritik', Old Testament Essays $1,26-48$.

Deist, F.E., 1983c, 'Probleme theologischer Verständigung in Südafrika', Old Testament Essays 1, 1-25.

Deist, F.E., 1984, 'John William Colenso: Biblical Scholar', Old Testament Essays 2, 98-132.

Deist, F.E., 1986a, 'Johannes Du Plessis en die Belydenisskrifte', Theologia Evangelica 19, 36-65.

Deist, F.E., 1986b, 'De Overleverings- en Traditiehistorische Methoden', in A.S. van der Woude (ed.), Inleiding tot de studie van het Oude Testament, pp. 159-172, Kok, Kampen.

Deist, F.E., 1988, Mosaic of Moses, Pentateuch Research since the Reformation, Tafelberg, Cape Town.

Du Plessis, J., 1919, The Life of Andrew Murray of South Africa, SCM, London.

Du Plessis, J., 1926a, 'De Inspiratie van de Schrift', Het Zoeklicht 4, 1926, 80-87.

Du Plessis, J., 1926b, 'De Inspiratie van de Schrift', Het Zoeklicht 4, 100-106.

Du Plessis, J., 1926c, 'Korrespondentie: de vertaling van 2 Timotheus 3:16', Het Zoeklicht 4, 118-119.

Du Plessis, J., 1926d, 'Korrespondentie: Schrifinspirasie', Het Zoeklicht 4, 148-150.

Du Plessis, J., 1927, 'Feit en Theorie in 't Inspiratiebegrip', Het Zoeklicht 4, 23-26.

Fensham, F.C., 1959, 'Thunder-stones in Ugarit,' Journal of Near Eastern Studies 18, 273-274. http://dx.doi.org/10.1086/371542

Fensham, F.C., 1960a, 'Exodus xxi 18-19 in the Light of Hittite law $\$ 10$, Vetus Testamentum 10, 333-335. http://dx.doi.org/10.1163/156853360X00319

Fensham, F.C., 1960b, 'The Legal Background of Mt. VI 12', Novum Testamentum 4, $1-2$.
Fensham, F.C., 1960c, 'The Treaty Between Solomon and Hiram and the Alalakh-Tablets', Journal of Biblical Literature 79, 59-60. http://dx.doi.org/10.2307/3264501

Fensham, F.C., 1962, 'Widow, Orphan and the Poor in Ancient Near Eastern Legal and Wisdom Literature', Journal of Near Eastern Studies 21, 129-139. http://dx.doi. org/10.1086/371679

Fensham, F.C., 1963, 'Clauses of protection in Hittite vassal treaties and the Old Testament', Vetus Testamentum 45, 133-143.

Fensham, F.C., 1970, Exodus, Callenbach, Nijkerk.

Ferreira, I.L., 1972, Die Teologiese Seminarium van Stellenbosch, 1858-1963, Makro Boeke, Pretoria.

Gabler, J.P., 1992, 'An Oration on the Proper Distinction between Biblical and Dogmatic theology and the Specific Objectives of Each', in B.C. Ollenburger, E.A.Martens \& G. Hasel (eds.), The flowering of Old Testament theology, pp. 489-502, Eisenbrauns, Winoka Lake.

Gadamer, H.G., 1990, Wahrheit und Methode, JCB Mohr, Tübingen.

Gadamer, H.G., 1993, Hermeneutik II, JCB Mohr, Tübingen.

Gerz, J.C \& Schmid, K., 2002, Abschied vom Jahwisten: Die Komposition des Hexateuch in der jüngsten Diskussion, Walter de Gruyter, Berlin. (BZAW 315).

Gottwald, N.K., 1985, The Hebrew Bible: A socio-literary introduction, Fortress, Philadelphia.

Grondin, J., 1994, Der Sinn für Hermeneutik, Wissenschaftliche Buchgesellschaft, Darmstadt.

Grondin, J., 2001, Einführung in die Philosophische Hermeneutik, Wissenschaftliche Buchgesellschaft, Darmstadt.

Gunkel, H., 1903, 'The Religio-Historical Interpretation of the New Testament', The Monist 13, 398-455. http://dx.doi.org/10.5840/monist190313331

Gunkel, H., 1926/1927, 'The "Historical Movement" in the Study of Religion', Expository Times 38, 532-536. http://dx.doi.org/10.1177/001452462703801202

Guy, J., 1983, The Heretic, Raven Press, Johannesburg.

Hanekom, T.N., 1959, Helperus Ritzema van Lier, NG Kerk-Uitgewers, Cape Town.

Hayes, J.H. \& Prussner, F.C., 1985, Old Testament Theology, SCM, London.

Hinchliff, P., 1964, John William Colenso Bishop of Natal, SCM, London.

Houtman, C., 1994, Der Pentateuch, Kok Pharos, Kampen.

Houtman, C., 2003, 'Colenso as Seen by Kuenen, and as Known from Colenso's Letters to Kuenen', in J. Draper (ed.), The Eye of the Storm, pp. 76-103, Cluster Publications, Pietermaritzburg.

Kaiser, O., 2003, Der Gott des Alten Testment, Vandenhoeck \& Ruprecht, Göttingen. Klapwijk, J., 1970, Tussen Historisme en Relativisme, Van Gorcum \& Comp, Assen.

Kraus, H-J., 1969, Geschichte der Historisch-Kritischen Erforschung des Alten Testaments, Neukirchener Verlag, Neukirchen-Vluyn.

Kuhn, T.S., 1970, Structure of scientific revolutions, University of Chicago Press, Chicago. Le Roux, J.H., 1992, 'The conversion of Andrew Murray', Studia Historiae Ecclesiastica 17(1), 43-60.

Le Roux, J.H., 1993, A Story of Two Ways, Verba Vitae, Pretoria.

Le Roux, J.H., 2001a, 'No Theory, No Science', Old Testament Essays 14(3), 444-457.

Le Roux, J.H., 2001b, "n Nuwe kyk op die Pentateug. Oor Eckart Otto se Pentateugondersoek', Nederduits Gereformeerde Teologiese Tydskrif 14(3), 234-244.

Le Roux, J.H., 2004, 'Die Mag van die Religieuse Idee', HTS Teologiese Studies/ Theological Studies 60(3), 743-753.

McBride, S.D., 1981, s.v. 'Deuteronomium', in G. Krause \& G. Müller (Hrsg.), Theologische Realenzyklopädie, De Gruyter, New York, vol. 8, pp. 530-543.

Mehlhausen, J., 1984, s.v. 'Geschichte/Geschichtsschreibung/Geschichtsphilosophie', in G. Krause \& G. Müller (Hrsg.), Theologische Realenzyklopädie, De Gruyter, New York, vol. 22, pp. 643-658.

Merk, O., 1984, s.v. 'Gabler, Johann Philipp (1753-1826)', in G. Krause \& G. Müller (Hrsg.), G. Krause \& G Müller (Hrsg.), Theologische Realenzyklopädie, De Gruyter, New York, vol. 22, pp. 1-3.

Moorrees, A., 1937, Die Nederduitse Gereformeerde Kerk in Suid-Afrika, 1652-1873, S.A. Bybelvereniging, Kaapstad.

Noth, M., 1972, A History of Pentateuchal Traditions, Prentice Hall, Englewood Cliffs.

Otto, E., 1997a, 'Das Deuteronomium als archimedischer Punkt der Pentateuchkritik. Auf dem Wege zu einer Neubegründung der de Wette'schen Hypothese', in J. Lust \& M. Vervenne (Hrsg.), Deuteronomy and Deuteronomic Literature, Festschrift C.H.W. Brekelmans, pp. 321-339, Peeters, Louvain.

Otto, E., 1997b, s.v. 'Recht/Rechtstheologie/Rechtsphilosophie vol. 1. Recht/ Rechtswesen im Alten Orient und im Alten Testament', in G. Krause \& G. Müller (Hrsg.), Theologische Realenzyklopädie, De Gruyter, New York, vol. 28, pp. 197-209.

Otto, E., 1998, s.v. 'Bundesbuch', in H.D. Betz \& D.S. Browning (Hrsg.), Religion in Geschichte und Gegenwart, Mohr Siebeck, Tübingen, 4th edn., vol. 1, pp. 876-187.

Otto, E., 1999a, s.v. 'Dekalog I. Altes Testament', in H.D. Betz \& D.S. Browning (Hrsg.), Religion in Geschichte und Gegenwart, Mohr Siebeck, Tübingen, 4th edn., vol. 2, pp. 625-628.

Otto, E.,1999b, Das Deuteronomium: Politische Theologie und Rechtsreform in Juda und Assyrien, Walter de Gruyter, Berlin. 
Otto, E., 1999c, s.v. 'Deuteronomium', in H.D. Betz \& D.S. Browning (Hrsg), Religion in Geschichte und Gegenwart, Mohr Siebeck, Tübingen, 4th edn., vol. 2, pp. 693-696.

Otto, E., 1999d, s.v. 'Ethik III. Biblisch, I. AT', in H.D. Betz \& D.S. Browning (Hrsg.) Religion in Geschichte und Gegenwart, Mohr Siebeck, Tübingen, 4th edn., vol. 2, pp. 1603-1606.

Otto, E., 1999e, 'Die Ursprünge der Bundestheologie im Alten Testament und im Alten Orient', Zeitschrift für Altorientalische und Biblische Rechtsgeschichte 4, 1-84.

Otto, E., 2000a, Das Deuteronomium im Pentateuch und Hexateuch. Studien zur Literaturgeschichte von Pentateuch und Hexateuch im Lichte des Deuteronomiumrahmens, JCB Mohr, Tübingen.

Otto, E., 2000b, s.v., 'Gerechtigkeit II. Biblisch. 1. Altes Testament', in H.D. Betz \& D.S Browning (Hrsg.), Religion in Geschichte und Gegenwart, Mohr Siebeck, Tübingen, 4 th edn., vol. 3, pp. 702-704.

Otto, E., 2000c, s.v. 'Gerichtsverfassung in Israel', in H.D. Betz \& D.S. Browning (Hrsg.) Religion in Geschichte und Gegenwart, Mohr Siebeck, Tübingen, 4th edn., vol. 3 pp. 741-743.

Otto, E., 2000d, s.v. 'Geschwisterethik', in H.D. Betz \& D.S. Browning (Hrsg.), Religion in Geschichte und Gegenwart, Mohr Siebeck, Tübingen, 4th edn., vol. 3, pp. 822-823.

Otto, E., 2000e, s.v. 'Gesetz II. Altes Testament', in H.D. Betz \& D.S. Browning (Hrsg.), Religion in Geschichte und Gegenwart, Mohr Siebeck, Tübingen, 4th edn., vol. 3 , pp. 845-848.

Otto, E., 2000f, s.v. 'Heiligkeitsgesetz', in H.D. Betz \& D.S. Browning (Hrsg.), Religion in Geschichte und Gegenwart, Mohr Siebeck, Tübingen, 4th edn., vol. 3, pp. 1570-1571.

Otto, E., 2000g, 'Mose und das Gesetz. Die Mosefigur als Gegenentwurf Politische Theologie zur neuassyrischen Konigsideologie im 7. Jh. v. Chr.', in E. Otto (Hrsg.), Mose: Agypten und das Alte Testament, pp. 43-83, Verlag Katholisches Bibelwerk, Stuttgart.

Otto, E., 2001a, Die Tora des Mose: Die Geschichte der Vermittlung von Recht, Religion und Politik durch die Mosegestalt, Berichte aus den Sitzungen de Joachim Jungius-Gesellschaft der Wissenschaften Hamburg 19/2, Vandenhoeck \& Ruprecht, Göttingen.

Otto, E., 2001b, 'Die Tora in Max Webers Studien zum Antiken Judentum. Grundlagen für einen religions- und rechtshistorischen Neuansatz in der Interpretation des biblischen Rechts', Zeitschrift für Altorientalische und Biblische Rechtsgeschichte 7, 1-188.

Otto, E., 2002a, Gottes Recht als Menschenrecht: Rechts- und literaturhistorische Studien zum Deuteronomium, Harrasowitz Verlag, Wiesbaden.

Otto, E., 2002b, Max Webers Studien des Antiken Judentums: Historische Grundlegung einer Theorie der Moderne, JCB Mohr, Tübingen.

Otto, E., 2002c, 'Politische Theologie in den Konigspsalmen zwischen Agypten und Assyrien: Die Herrscherlegitimation in den Psalmen 2 und 18 in ihren altorientalischen Kontexten', in E. Otto \& E. Zenger (Hrsg.), 'Mein Sohn bist du' (Ps 2,7). Studien zu den Königspsalmen, pp. 43-83, Verlag Katholisches Bibelwerk, Stuttgart.

Otto, E., 2005, 'The Pentateuch between synchrony and diachrony', in E. Otto \& J.H. le Roux (eds.), A critical study of the Pentateuch: An Encounter Between Europe and Africa, pp. 22-49, Lit, Münster.

Otto, E., 2007a, 'A hidden truth behind the text or the truth of the text: at a turning point in biblical scholarship two hundred years after De Wette's Dissertation Critico-Exegetica', in J.H. le Roux \& E. Otto (eds.), South African perspectives on the Pentateuch between synchrony and diachrony, pp. 19-28, T\&T Clark, London.

Otto, E., 2007b, 'The pivotal meaning of Pentateuch research for a history of Israelite and Jewish religion and society', in J.H. le Roux \& E. Otto (eds.), South African perspectives on the Pentateuch between synchrony and diachrony, pp. 29-53, T\&T Clark, London.

Pakenham, T., 1991, The Scramble for Africa, Raven Press, Johannesburg.

Pannenberg, W.H., 1970, Basic Questions in Theology, vol. 1, SCM, London.
Popper, K., 1963, Conjectures and refutations, Routledge \& Kegan Paul, London. Popper, K., 1968, The logic of scientific discovery, Routledge \& Kegan Paul, London. Reardon, B.M., 1966, Religious Thought in the Nineteenth Century, Cambridge Press, Cambridge. http://dx.doi.org/10.1017/СBO9780511554766

Rogerson, J., 1984, Old Testament Criticism in the Nineteenth Century, SCM, London.

Rogerson, J., 2003, 'Colenso in the World of Nineteenth Century Intellectual Ferment', in J. Draper (ed.), The Eye of the Storm, pp. 127-135, Cluster Press, Pietermaritzburg.

Saebø, M., 1987, 'Johann Philipp Gablers Bedeutung für die biblische Theologie', Zeitschrift für die Alttestamentliche Wissenschaft 99, 1-16. http://dx.doi. org/10.1515/zatw.1987.99.1.1

Sandys-Wunsch, J. \& Eldredge, L., 1980, J.P. Gabler and the Distinction between Biblical and Dogmatic Theology: Translation, Commentary and Discussion of his originality', Scottish Journal of Theology 33, 133-158. http://dx.doi.org/10.1017/ S0036930600047311

Schmid, K., 1999, Erzväter und Exodus, Neukirchener Verlag, Neukirchen-Vluyn.

Schmidt, L., 1991, s.v. 'Literarkritik 1', in G. Krause \& G Müller (Hrsg.), Theologische Realenzyklopädie, De Gruyter, New York, vol. 21, pp. 211-222.

Schmidt, W.H., 1989, 'Einleitung und Theologie', in W.H. Schmidt \& W. Thiel (Hrsg.), Altes Testament, Grundkurs Theologie, vol. 1, pp. 9-88, Verlag Katholisches Bibelwerk, Stuttgart.

Schweitzer, A., 1936, The quest of the historical Jesus, A \& C Black, London.

Seebass, H., 1982, s.v. 'Elohist', in G. Krause \& G. Müller (Hrsg.), Theologische Realenzyklopädie, De Gruyter, New York, vol. 9, pp. 520-524.

Seebass, H., 1987, s.v. 'Jahwist', in G. Krause \& G. Müller (Hrsg.), Theologische Realenzyklopädie, De Gruyter, New York, vol. 16, pp. 441-451.

Seebass, H., 1996, s.v. 'Pentateuch', in G. Krause \& G. Müller (Hrsg.), Theologische Realenzyklopädie, De Gruyter, New York, vol. 26, pp. 185-209.

Thiselton, A.C., 1980, The Two Horizons, Pater Noster, Exeter.

Troeltsch, E., 1913, 'Historiography', in J. Hastings (ed.), Religion and ethics, pp. 716-730, T\&T Clark, Edinburgh.

Troeltsch, E., 1922, 'Ueber Historisch und Dogmatische Methode in der Theologie', in E. Troeltsch (Hrsg.), Gesammelte Schriften, vol. 2, pp. 729-753, JCB Mohr, Tübingen.

Van der Watt, P.B., 1979, John Murray, 1826-1882, NG Kerkboekhandel, Pretoria.

Van Selms, A.S., 1976, Genesis, vol. 1, Kok, Kampen.

Van Zyl, A.H., 1976, God's word in human speech, vol. 1, Butterworths, Durban.

Von Rad, G., 1958, Theologie des Alten Testaments, vol. 1, Chr. Kaiser Verlag, München.

Von Rad, G., 1960/1961, 'History and the patriarchs', Expository Times 72, 213-216. http://dx.doi.org/10.1177/001452466107200707

Von Rad, G., 1967, Theology of the Old Testament, SCM, London.

Von Rad, G., 1971, 'Das Formgeschichtliche Problem des Hexateuch', in G. von Rad (Hrsg.), Gesammelte Studien zum Alten Testament, pp. 9-86, Kaiser, München.

Von Rad, G., 1973, 'Offene Fragen im Umkreis einer Theologie des AltenTestaments', in G. von Rad (Hrsg.), Gesammelte Studien zum Alten Testament, vol. 2, pp. 289-312, Kaiser, München.

Vorster, W.S., 1971, 'Moderne Linguïstiek en Bybelnavorsing', Theologia Evangelica $4(2), 139-148$

Weber, M., 1949, The Methodology of the Social Sciences, The Free Press, New York.

Wellhausen, J., 2001, Prolegomena zur Geschichte Israels, Walter de Gruyter, Berlin. http://dx.doi.org/10.1515/9783110869583

Zenger, E., 1997, s.v. 'Priesterschrift', in G. Krause \& G. Müller (Hrsg.), Theologische Realenzyklopädie, De Gruyter, New York, vol. 27, pp. 435-446.

Zenger, E. (Hrsg.), 1998, Einleitung in das Alte Testament, Kohlhammer, Stuttgart. 